\title{
SEDIMENTARY-VEGETATION RESPONSE TO THE CHANNEL BY-PASS: A CASE STUDY OF THE DANUBE RIVER
}

\section{ŠÁRKA HORÁČKOVÁ ${ }^{1}$, MILAN LEHOTSKÝ $^{2}$,TOMÁŠ ŠTEFANIČKA ${ }^{3}$, ISTVÁN VICZIÁN ${ }^{4}$}

${ }^{1}$ Department of Physical Geography and Geoecology, Comenius University in Bratislava, Mlynská dolina, Ilkovičova 6, 842 15, Bratislava, Slovak Republic; e-mail: sarka.horackova@uniba.sk

${ }^{2}$ Section of Physical Geography, Geomorphology and Natural Hazards, Slovak Academy of Sciences, Štefánikova 49, 81473 Bratislava, Slovak Republic; e-mail:geogleho@savba.sk

${ }^{3}$ Department of Theoretical Geodesy, Slovak University of Technology in Bratislava, Radlinského 11, Block A, 810 05 Bratislava, Slovak Republic; e-mail: tomas.stefanicka@stuba.sk

${ }^{4}$ Department of Physical Geography, Geographical Institute, Hungarian Academy of Sciences Budaörsi str. 45 (MTA Research Building), H - 1112 Budapest, Hungary; e-mail: viczian.istvan@csfk.mta.hu

\begin{abstract}
Horáčková Š., Lehotský M., Štefanička T., Viczián I.: Sedimentary-vegetation response to the channel by-pass: A case study of the Danube river. Ekológia (Bratislava), Vol. 36, No. 2, p. 172-183 , 2017.

The Gabčíkovo-Nagymaros waterworks construction on Danube river in Slovakia (1977-1992) was followed with major ecological consequences. The water level and flow velocity was decreased in the original by-passed channel in order to keep high water level for shipping in the bypass canal. The decrease in discharge and lowering flow velocity resulted in the channel narrowing and increase in the vertical accretion magnitude in new floodplain pockets along both sides of by-passed channel. What is more, anthropic intervention in form of groynes structures built for channel adjustment before 1992 dramatically accelerated this process. Vegetation colonisation took place on the new floodplain. In this paper, we analysed land cover changes - vegetation succession using aerial photographs taken in 1986, 1996, 2004 and 2013 as well as field surveys. After the flood in 2013 , the area of the new floodplain reached $57 \%$ (310 ha) of the original channel area.
\end{abstract}

Key words: Danube, by-passed channel, land cover, alluvial forest, succession.

\section{Introduction}

The Danube river and its floodplain were subject to increased urbanisation, channel regulation and its modification for shipping during the past three centuries. Owing to the construction of several dams upstream Bratislava in Germany and Austria, the character of the bed load and its regime has changed substantially too. Only suspended load comes from upstream and forms a new sandy levee downstream Bratislava (Globevnik, Mikoš, 2009; Lehotský et al., 2010). Furthermore, the construction of Gabčíkovo-Nagymaros waterworks (1992) because of the decrease in discharges in the by-passed channel contributed, on one hand, to its narrowing and degradation and, on the other hand, to the development of new floodplain along its banks (Fig. 1). 
Góczán and Lóczy (1990) draw possible negative impact on the surrounding areas by changing the water level in the original river. Their preliminary study pointed out probable destruction of local protected areas of sidearms as a result of the change in the underground water scheme. However, as described in the works of Otahelová et al. (2007), the water plant communities thrive, thanks to the sandy sediments accumulated at the by-passed channel, especially near groynes as shown in Fig. 2 (Lehotský et al., 2013; Klasz et al., 2014). As a result, a dynamic riparian forest has developed and poses the main cause of the increased river channel roughness because of the vegetation and biomass (Vojtková et al., 2014).

The aim of this paper is to present the sedimentary-vegetation changes from aerial photographs prospection to point out new floodplain formation and channel narrowing as well as vegetation succession.
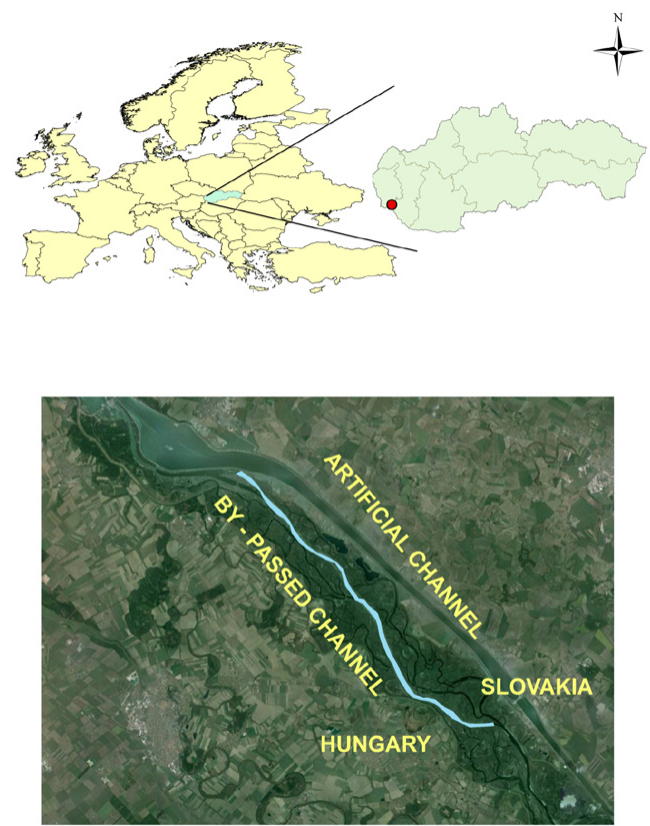

by-passed (old) Danube river channel

Fig. 1. Study area of the by-passed Danube river channel.

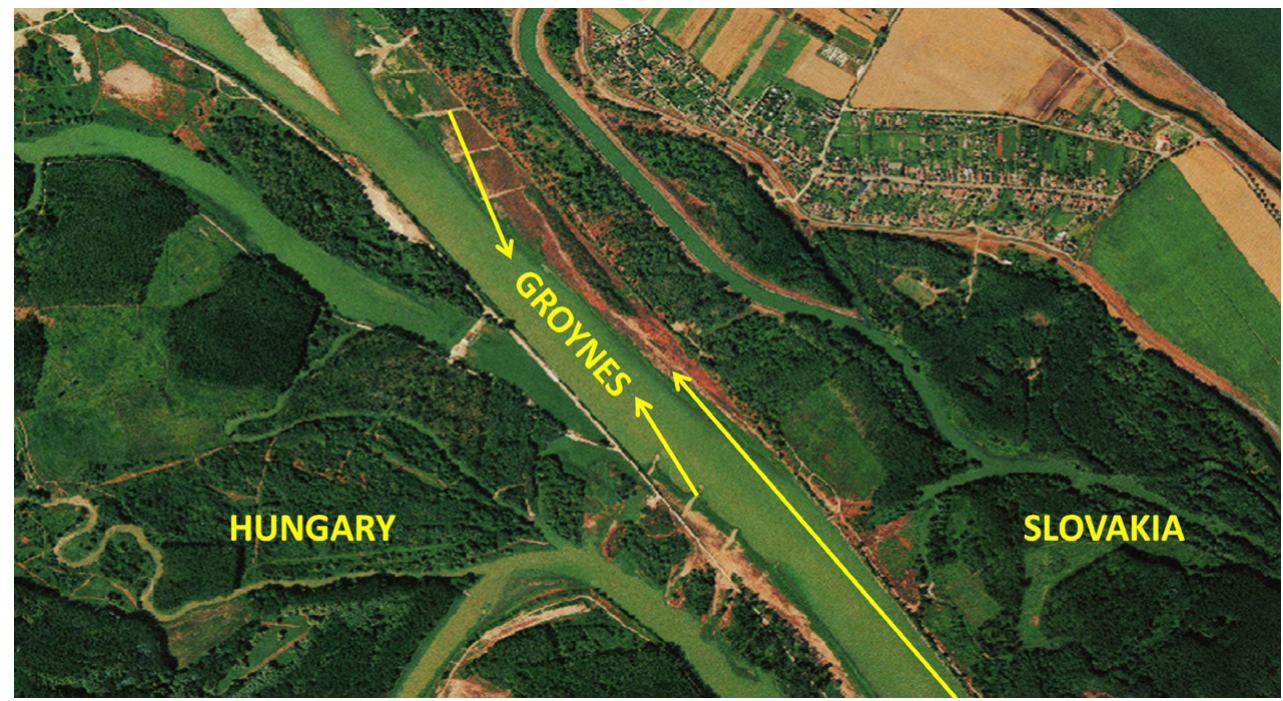

Fig. 2. Groynes structures in the by-passed Danube river channel in 1996. 


\section{Material and methods}

Anthropic adjustments in the Danube river channel in Slovakia

Flood events on the Danube river were recorded since the presence of the human settlements (Pekárová et al., 2013). Hence, there were major efforts to cut Danube from its oxbow system and concentrate the flow into the main channel. Flood protection embankments were reconstructed several times to its current stage with various channel modifications that are built to accelerate waterways transportation (Jansky et al., 2004). One of these modifications was named groynes (Szlauer-Lukaszewska, 2015; Klasz et al., 2014). They are hydrotechnical adjustments to the channel curves to deepen the water traffic trajectory. Unfortunately, such anthropic landforms conditioned increase in sedimentation processes, often resulting in bar formations.

\section{Gabčíkovo-Nagymaros waterworks and sedimentation}

In case of the vertical accretion, the floodplain pockets are the major landform structures as shown in Fig. 3 (Liébault, Piégay, 2002). After the commissioning of the waterworks, new floodplain pockets began to developing the by-passed, old Danube channel. Owing to several problems (economical, social, ecological or political), Slovakia begun to build water scheme without the support of Hungary (Jansky et al., 2004). The main disadvantages of this decision were major ecological consequences in surrounding areas (Lehotský et al., 2013; Illyová, Matečný, 2014; Otahelová et al., 2007; Jansky et al., 2004).

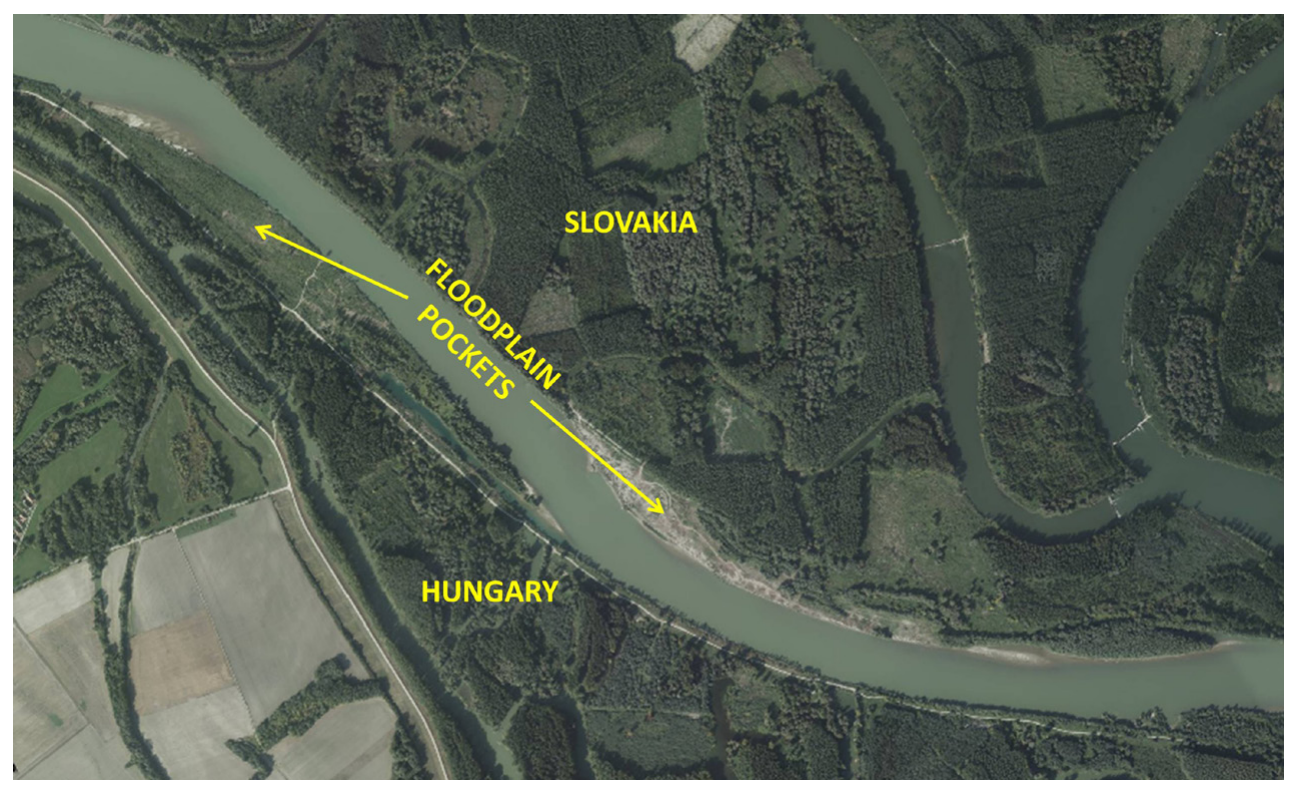

Fig. 3. Sedimentation (floodplain pockets) in the Danube river channel in 2013 caused by anthropogenic landforms groynes near Vojka village.

Average annual discharge in the by-passed Danube river channel (measured in section $1848,4 \mathrm{rkm}$ ) was decreased after waterworks initiation in 1993 from 1900 to $350 \mathrm{~m}^{3} \mathrm{~s}^{-1}$, resp. to $220 \mathrm{~m}^{3} \mathrm{~s}^{-1}$ in 1994 (in the winter) and maximum current velocities declined from 2.0-3.5 to $1 \mathrm{~m} \mathrm{~s}^{-1}$ (Vranovský, 1997; Illyová, Matečný, 2014). Landforms accumulation on groynes started to form a scrollbar that has developed into floodplain pockets. However, during 
this period, the vegetation succession took place in the areas above the mean water level in the channel resulting in riparian forest. According to Nakamura et al. (1997), riparian stand can be formed in single vegetation season.

\section{Forestry management intervention and protected areas}

Fortunately, the protected areas on both sides of the river channel (the Danubian lowlands protection area in the Slovak side and Szigetköz landscape protection area in the Hungarian one) were saved from the direct destruction. However, the current stage of this sidearm system is far from its pristine, as the discharge flow direction and sedimentary accumulation processes have changed from its natural state.

Some parts of the oxbow lakes system dried out. The natural alluvial forest was removed, and Populus $x$ canadiensis was seeded in order to produce the fast growing quality wood. This type of forest is not essential, as it supports invasive plant species (Solidago gigantea) (Uherčíková, Némethová, 2006).

Monitoring of the surrounding area has been proceeding for years to observe the damage and changes in local plant and animal communities. Nowadays, there is a huge effort to declare this area as a Natural Park Protection Area connected to the similar one on the upper part of the Danube river in Austria (Donau-Auen National Park). Yet the area of new sedimented floodplain accumulated in 26 years is considered to be as a part of the channel that does not belong to the protected areas of Dunajské luhy. Hence, it is important to distinguish between necessary flood protection management felling and required natural conservation.

\section{Analysis of the orthophotomaps}

Represented land cover change was evaluated from the monochromatic (1986) and pan-

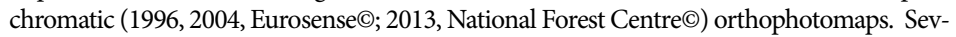
en landcover classes were distinguished:

1. alluvial forest,

2. bushes,

3. grasslands,

4. gravel bed,

5. sandy accumulation,

6. wet depressions,

7. reeds.

The areas of these land cover types were calculated and visualised in Geographic Information System (GIS) ESRI ArcGIS v.10.1. Ten landforms were presented during its development in 1996, 2004 and 2013. Half of them were localised on the Hungarian side of the river.

\section{Field work}

Current stage of sedimentation and vegetation succession was validated directly during field surveys. Several fytocenology records were made on the places of initial forest stage development using Braun-Blanquet (1964) type of fytocenology recording. Succession stage was evaluated as initial (primary), established (secondary) or climax (tertiary). Vegetation was monitored during the season in 2013.

\section{Results}

Each floodplain pocket in the channel has its typical shape and system of landforms (Fig. 4). Each of these landforms rose after building of anthropogenic landforms - groynes. Below these landforms, river flow begins swirling, what is encouraging the sediments to accumulate on these places.

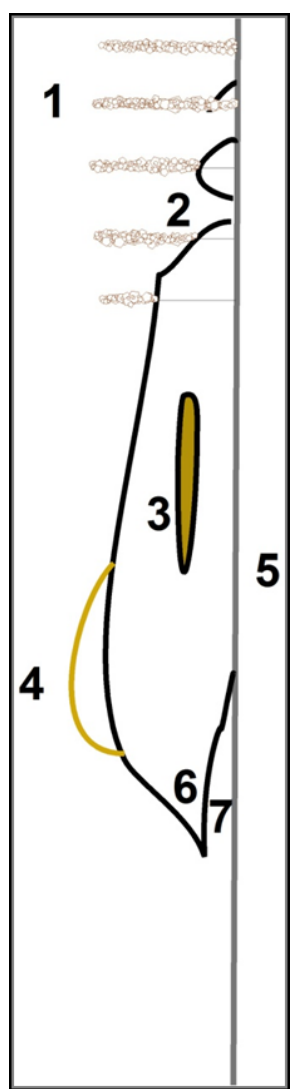

Fig. 4. Scheme of fluvial landforms on the sedimented floodplain pocket in the by-passed Danube river channel (1 - groynes; 2 - accumulation bank; 3 - crest of the pocket - previous scroll bar; 4 - island/peninsula; 5 - original artificial dyke; 6 - tail; 7 - cove). 
Vegetation succession is naturally following the sedimentation process. As these new landforms rise, this space is now being occupied by the initial vegetation species of the alluvial forest. Without forest management, it develops to the final climax stage.

\section{Development of the vegetation succession from 1988 to 2013}

First vegetation in the channel was visible on the oldest orthophotomaps from the 1986, even before the by-passed channel formation begun. Next orthophotomaps (1996) are pointing on the increased area of scrollbars (Fig. 5) that consequently created a new area of the floodplain in the channel. Afterwards, vegetation succession took place on these sandy sediments. Water Management Institute in cooperation with Forest Management in Slovakia and Hungary cuts this initial forest regularly on both sides of the river. This intervention increases the amount of woody debris accumulated by the flood sand that might cause blockage during the major floods, because some of the fallen wood is not transported away. On the other hand, some in-channel parts were left out of deforestation and, therefore, accumulate greater amount of sediments. Vege-

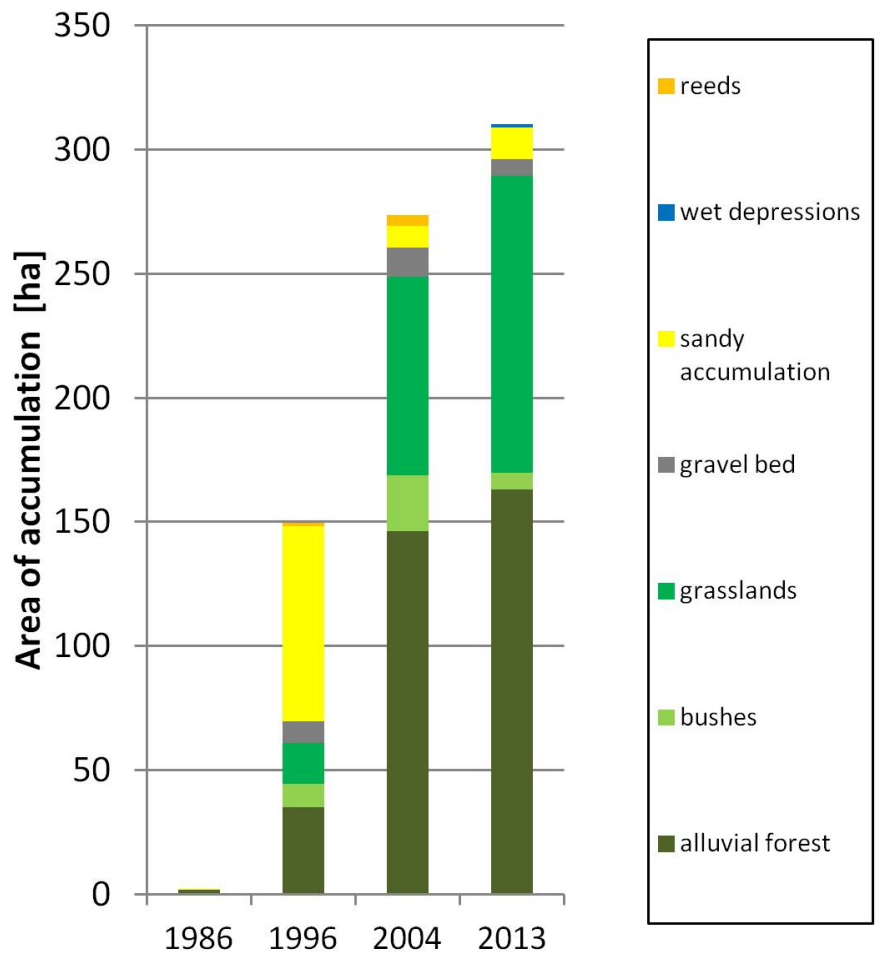

Fig. 5. Change in the in-channel accumulation over the water level and land cover changes from 1986 to 2013. tation is nearly impenetrable and might cause higher friction on these scrollbars in the river channel.

Grasslands are located mainly on the places of initial succession process and elevated bars. The gravel bed acts as a fast water absorption platform making the soil profile very dry, so the stems of the trees cannot reach the ground water regularly throughout the year. It is not possible to avoid channel infilling without increasing the water levels in the by-passed Danube river channel. Alluvial forests and grasslands provide new habitat for local zoocenosis. 


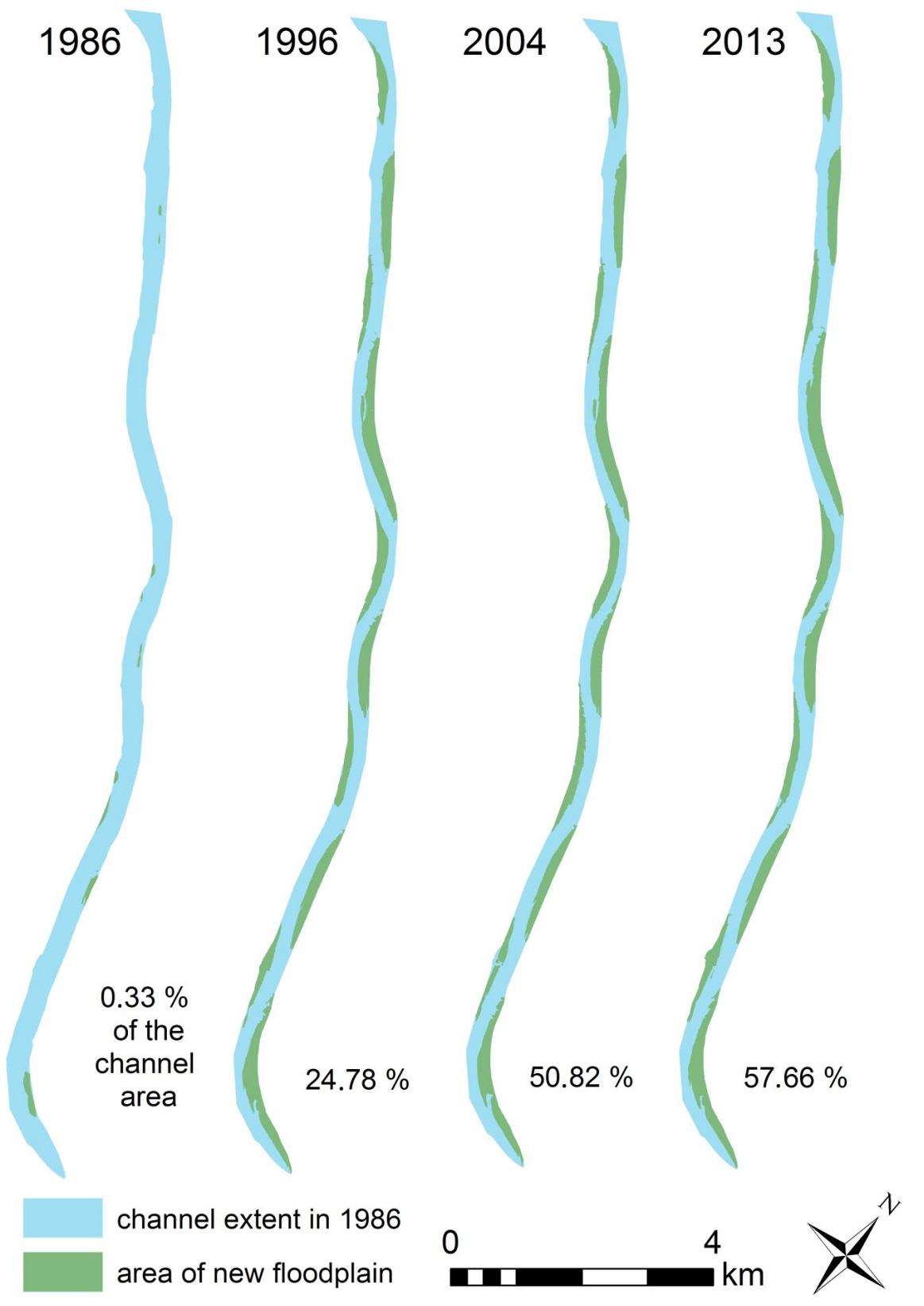

Fig. 6. Area of in-channel sedimentation over the water level in the by-passed Danube river channel. 


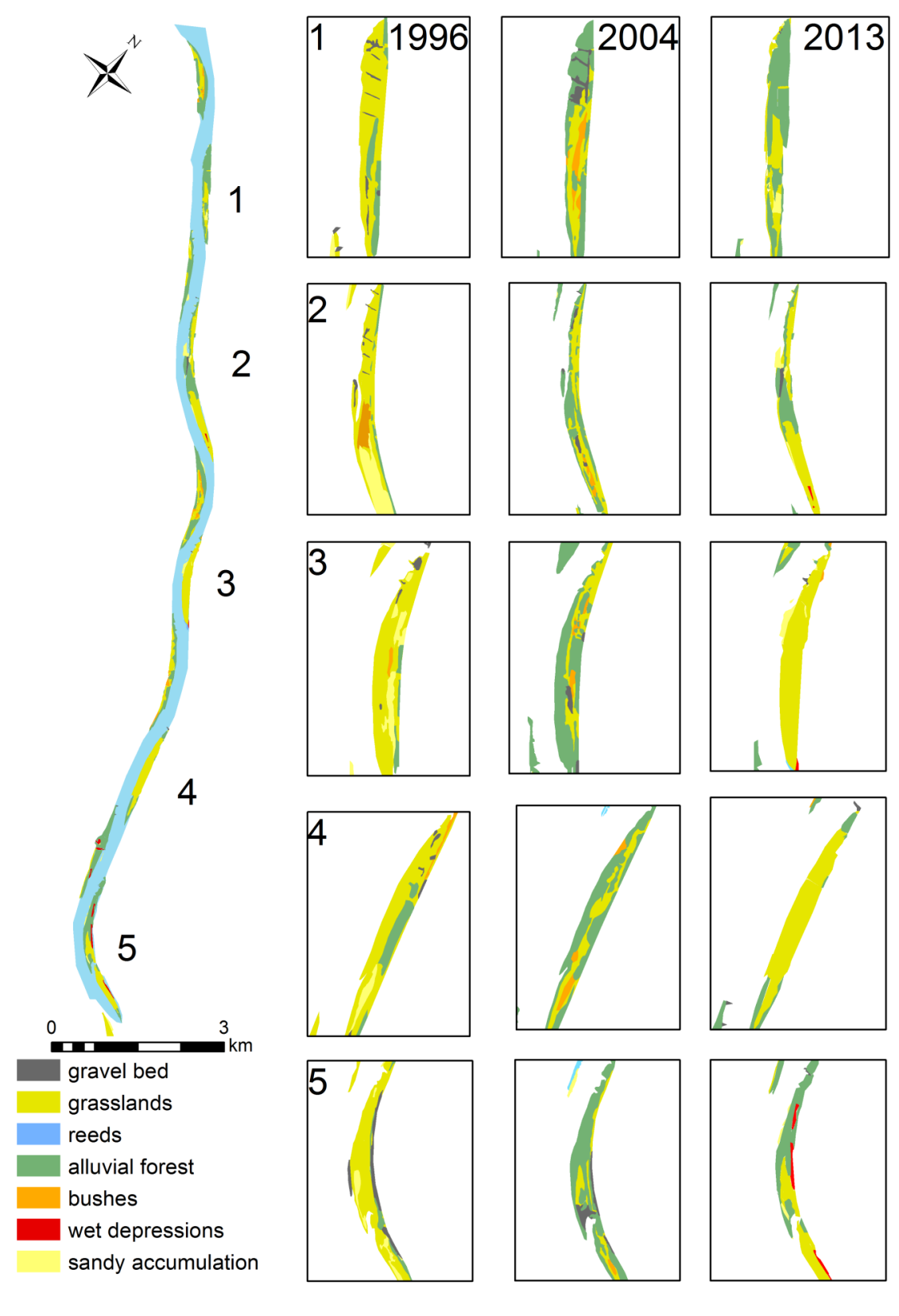

Fig. 7. Land cover changes of the channel (Slovakia). 

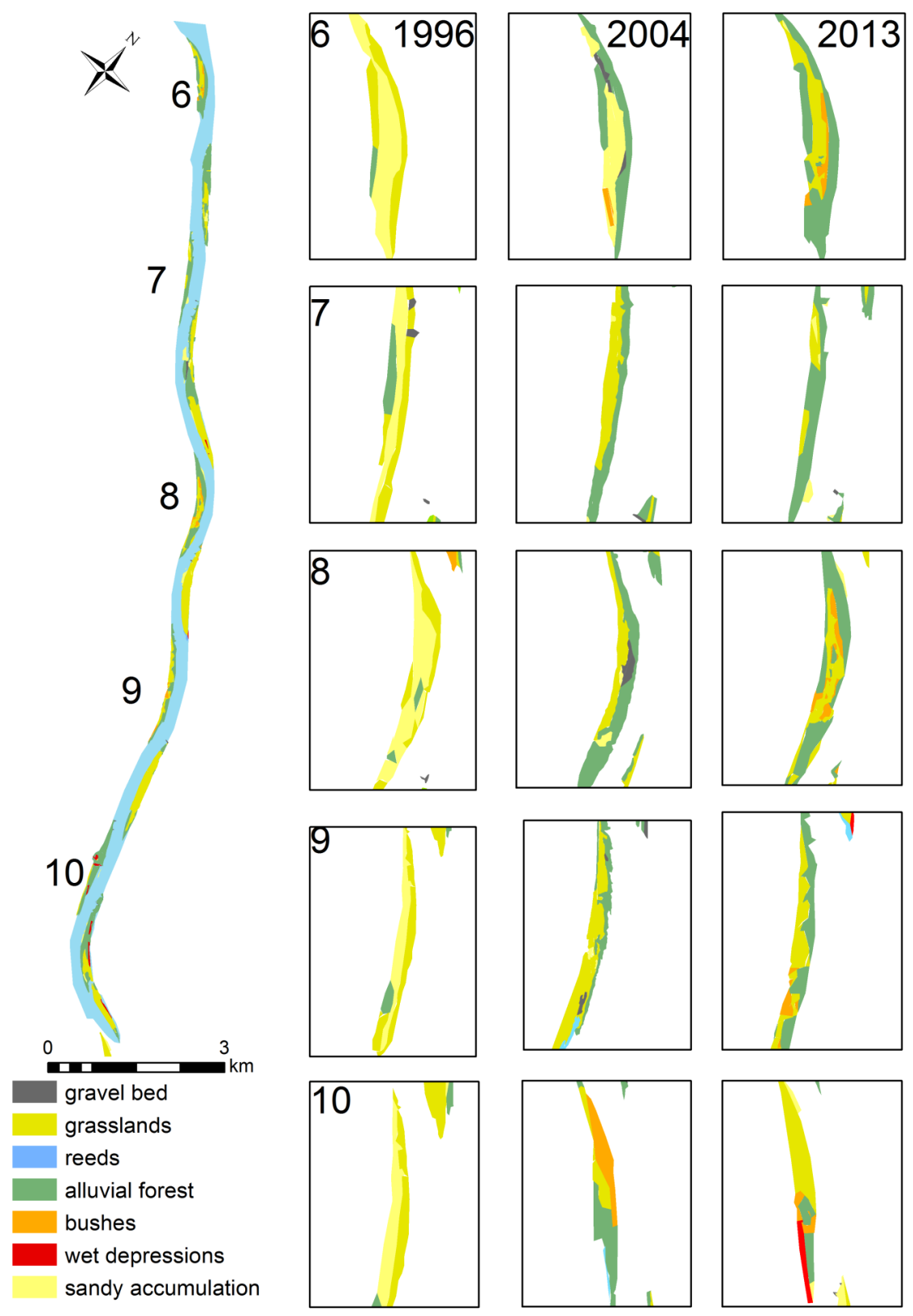

Fig. 8. Land cover changes of the channel (Hungary). 
T a b l e 1. Fytocenology record on the previous scrollbar on the floodplain pocket 1.

\begin{tabular}{|c|c|c|c|c|c|c|c|c|c|c|c|c|c|c|c|c|c|c|c|c|}
\hline \multirow{3}{*}{$\begin{array}{l}\text { No. of relevé: } \\
\text { No. of species: } \\
\text { Floor } \\
\end{array}$} & \multicolumn{4}{|c|}{1} & \multicolumn{4}{|c|}{2} & \multicolumn{4}{|c|}{3} & \multicolumn{4}{|c|}{4} & \multicolumn{4}{|c|}{5} \\
\hline & \multicolumn{4}{|c|}{13} & \multicolumn{4}{|c|}{16} & \multicolumn{4}{|c|}{14} & \multicolumn{4}{|c|}{10} & \multicolumn{4}{|c|}{7} \\
\hline & $\mathrm{E}_{3-1}$ & $\mathrm{E}_{3-2}$ & $\mathrm{E}_{2}$ & $E_{1}$ & $E_{3-1}$ & $\mathrm{E}_{3-2}$ & $\mathrm{E}_{2}$ & $E_{1}$ & $E_{3-1}$ & $\mathrm{E}_{3-2}$ & $\mathrm{E}_{2}$ & $\mathrm{E}_{1}$ & $E_{3-1}$ & $\mathrm{E}_{3-2}$ & $\mathrm{E}_{2}$ & $\mathrm{E}_{1}$ & $E_{3-1}$ & $\mathrm{E}_{3-2}$ & $\mathrm{E}_{2}$ & $E_{1}$ \\
\hline Acer negundo & 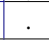 & . & . & . & . & 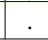 & + & . & 2 & . & . & . & . & . &. & . & . & . & $\mathrm{R}$ & . \\
\hline Populus alba & . & . & . & . & 2 & 1 & . & . & . & . & . & . & . & . & . & . & . & . & . & . \\
\hline Populus nigra & . & . & . & . & 1 & . & . & . & . & . & . & . & 1 & + & . & . & . & . & . & . \\
\hline Salix alba & 2 & 1 & . & . & 2 & 1 & 1 & . & 1 & 1 & . & . & . & . & . & . & . & . & . & . \\
\hline Cerasus avium & . & . & . & . & . & . & . & . & . & . & . & . & . & . & . & . & . & . & + & . \\
\hline Cornus sanguinea & . & . & 1 & $\mathrm{R}$ & . & . & 2 & . & . & . & . & . & . & . & . & . & . & . & . & . \\
\hline Eonymus europaeus & . & . & . & . & . & . & . & $\mathrm{R}$ & . & . & . & $\mathrm{R}$ & . & . & . & . & . & . & . & . \\
\hline Malus sp. & . & . & . & . & . & . & . & . & . & . & . & . & . &. & . & $\mathrm{R}$ & . & . & . & . \\
\hline Prunus sp. & . & . & . & $\mathrm{R}$ & . & . & . & $\mathrm{R}$ & . & . & . & $\mathrm{R}$ & . &. & . & . & . & . & . & . \\
\hline Ribes rubrum & . & . & $\mathrm{R}$ & . & . & . & + & $\mathrm{R}$ & . & . & . & . & . &. & . & . & . & . & . & . \\
\hline Rosa sp. & . & . & . & . & . & . & . & . & . & . & . & . & . & . & $\mathrm{R}$ & $\mathrm{R}$ & . & . & . & . \\
\hline Rubus caesius & . & . & + & $\mathrm{R}$ & . & . & . & . & . & . & . & . & . &. &. & + & . & . & . & . \\
\hline Sambucus nigra & . & . & . & + & . & . & . & . & . & . & . & . & . & . & . & . & . & . & $\mathrm{R}$ & . \\
\hline Aster lanceolatus &. & . & . & 1.2 & . & . &. & 2.2 &. & . &. & 1.2 & . &. &. & 2.2 &. & . & . & . \\
\hline Aegopodium podagraria & . & . & . & $\mathrm{R}$ & . & . & . & . & . & . & . & $\mathrm{R}$ & . & . & . & . & . & . & . & . \\
\hline Anthriscus cf. sylvestris & . & . & . & $\mathrm{R}$ & . & . & . & . & . & . & . & $\mathrm{R}$ & . & . & . & . & . & . & . & . \\
\hline Arctium cf. lapta & . & . & . & . & . & . & . & $\mathrm{R}$ & . & . & . & $\mathrm{R}$ & . & . & . & $\mathrm{R}$ & . & . & . & . \\
\hline Cerasus avium & . & . & . & . & . & . & . & . & . & . & . & . & . & . & . & $\cdot$ & . & . & . & . \\
\hline Cardamine sp. & . & . & . & . & . & . & . & . & . & . & . & . & . & . & . & $\mathrm{R}$ & . & . & . & . \\
\hline Galium aparine & . & . & . & 1.2 & . & . & . & 3.3 & . & . & . & 1 & . & . & . & + & . & . & . & + \\
\hline Lamium purpureum & . & . & . & . & . & . & . & . & . & . & . & 2.3 & . & . & . & . & . & . & . & 1 \\
\hline Leontodon autumnalis & . & . & . & . & . & . & . & . & . & . & . & . & . & . & . & . & . & . & . & + \\
\hline Poaceae sp. & . & . & . & 1.2 & . & . & . & 2.2 & . & . & . & 1.2 & . & . & . & 2.2 & . & . & . & 2.2 \\
\hline Phalaris arundinacea & . & . & . & . & . & . & . & + & . & . & . & . & . & . & . & 2.2 & . & . & . & 5.4 \\
\hline Stellaria media & . & . & . & 1.3 & . & . & . & 1.2 &. & . & . & 3.3 & . & . & . &. & . & . & . & . \\
\hline Symphytum officinale & . & . & . & . & . & . & . & $\mathrm{R}$ & . & . & . & . & . & . & . & . & . & . & . & . \\
\hline Taraxacum officinale & . & . & . & . & . & . & . & . & . & . & . & $\mathrm{R}$ & . & . & . & . & . & . & . & . \\
\hline Urtica dioica & . & . & . & 1.2 & . & . & . & 3.3 & . & . & . & 2.2 & . & . & . & . & . & . & . & \\
\hline
\end{tabular}

\section{Localisation of the recordings:}

1. Dobrohošt ( $\left(47^{\circ} 59^{\prime} 04,6665647^{\prime \prime} \mathrm{N}, 17^{\circ} 20^{\prime} 46,54015^{\prime \prime} \mathrm{E}\right)$, area $400 \mathrm{~m}^{2}, \mathrm{E}_{3-1} 20 \%, \mathrm{E}_{3-2} 5 \%, \mathrm{E}_{2} 1 \%, \mathrm{E}_{1} 7 \%, 18.04 .2013$.

2. Dobrohošt $\left(47^{\circ} 58^{\prime} 50,29802^{\prime \prime} \mathrm{N}, 17^{\circ} 21^{\prime} 08,90172^{\prime \prime} \mathrm{E}\right)$, area $400 \mathrm{~m}^{2}, \mathrm{E}_{3-1} 15 \%, \mathrm{E}_{3-2} 7 \%, \mathrm{E}_{2} 15 \%, \mathrm{E}_{1} 65 \%, 18.04 .2013$.

3. Dobrohošt ( $47^{\circ} 58^{\prime} 59,61971^{\prime \prime} \mathrm{N}$. , 17 $\left.7^{\circ} 20^{\prime} 56,40995^{\prime \prime} \mathrm{E}\right)$, area $400 \mathrm{~m}^{2}, \mathrm{E}_{3-1} 25 \%, \mathrm{E}_{3-2} 3 \%, \mathrm{E}_{2} 1 \%, \mathrm{E}_{1} 75 \%, 18.04 .2013$.

4. Dobrohošt ( $\left.47^{\circ} 58^{\prime} 48,90798^{\prime \prime} \mathrm{N}, 17^{\circ} 21^{\prime} 07,73620^{\prime \prime} \mathrm{E}\right)$, area $400 \mathrm{~m}^{2}, \mathrm{E}_{3-1} 10 \%, \mathrm{E}_{3-2} 1 \%, \mathrm{E}_{2} 2 \%, \mathrm{E}_{1} 35 \%, 18.04 .2013$.

5. Dobrohošt ( $47^{\circ} 58^{\prime} 50,29802^{\prime \prime} \mathrm{N}, 17^{\circ} 21^{\prime} 08,90172^{\prime \prime} \mathrm{E}$ ), area $100 \mathrm{~m}^{2}, \mathrm{E}_{3-1} 0 \%, \mathrm{E}_{3-2} \mathrm{O} \%, \mathrm{E}_{2} 2 \%, \mathrm{E}_{1} 100 \%, 18.04 .2013$.

The major change in the channel is formed by floodplain pockets formation that originated from the scrollbars. Their area increased from 1.79 ha in 1986 to 310 ha in 2013, what represents $57 \%$ of the channel. Every landform developed its own vegetation succession (Figs 6-8) ranging from initial vegetation stage to the developed alluvial forest. Human impact is noticeable in this area. The trees are regularly cut down and the succession is often disrupted. Most of the sandy scrollbars were colonised by grasslands and later with initial alluvial forest 
that is now the major land cover type. Typical alluvial forest is represented by Salici-Populetum community as observed in vegetation prospection on the flood pocket 1 . Conspicuously, the vegetation succession is still in the progress and the current succession stage is initial alluvial forest (Table 1).

\section{Channel changes and sedimentation}

Below the initial forest coverage, avulsions are visible as well as depressions and the manmade forest roads are interfering with the natural character of the local land surface. New banks of the river formed by this accumulation are not stabilised with the embankment and so it opens the possibility of the natural channel migration.

Variability of the alluvial sediments in the old Danube river channel depends on the allocation within the floodplain. Also sedimentation is different near the banks that are flooded more often than the rest of the bar. At first, there was an island formation seen on several parts of the channel. The upper part was continuously connecting the island to the bank with each new layer of sandy fluvial sediments. Land surface formation depends highly on the flow velocity and its duration during floods, as it is the main driving force in the land surface evolution in this area. Channel became significantly narrower compared to the width in 1986.

\section{Discussion}

Prevalence of the fine sediments in the middle channel of Danube river began with the era of building several dams on the upper channel. Gravel sediments stayed stranded in these dams and so the silty and sandy sediments in the lower reaches became predominant (Liébault, Piégay, 2001; Surian, 1999). Character of the river bed, sediment transportation and accumulation has changed. The problem of vertical sedimentation is not limited to the by-passed Danube river channel. It was described near Bratislava on the upper part of the by-passed Danube river channel (Lehotský et al., 2010). The stability of this phenomenon in the different parts of the channel is questionable. The important part of the sediment movement takes place under the water level in the river flow.

In the Donau-Auen National Park, the closest prospected research area, the overbank deposits were estimated to be $416,000 \mathrm{~m}^{3} \mathrm{yr}^{-1}$ as $20 \%$ of the transported load (Klasz et al., 2014). Similar analysis was carried out by Allred and Schmidt (1999) with focus on vertical accretion along the Green river in Utah in the United States. The scope was to compare the Green river channel between years 1938 and 1993 . The study proved that $82 \%$ of the area was still considered to be active channel. This represents strong contrast between the Danube channel with only $43 \%$ of the area considered to be active channel.

\section{Conclusion}

Orthophotomaps investigation proved the major vertical accretion formation and channel narrowing. The area of floodplain above the annual water level in the channel increased from 
1.78 ha in 1986 to 310 ha in 2013 . That represents $57 \%$ of the active channel area before the waterworks construction begun. The channel friction is increasing as well because of the vegetation succession. The hydrotechnical intervention as deforestation of these areas puts vegetation stage to the start, but the vegetation recovery of the alluvial forest is very fast and this solution could be unsustainable both economically and ecologically. Also new fluvial landforms, called floodplain pockets, formed from initial scrollbars. Even though every bar has its specific system of sedimentation patterns during floods, typical fluvial landforms can be identified on every floodplain pocket in the field. Further research and monitoring is still required to consider the flood protection in the area and to obtain the information for efficient river and forest management. This has to be reconsidered in the context of possibility of new national park declaration whether to include or exclude new floodplain in the by-passed Danube river channel.

\section{References}

Allred, T.M. \& Schmidt J.C. (1999). Channel narrowing by vertical accretion along the Green River near Green River Utah. Geological Society of America Bulletin, 111(12), 1757-1772. DOI: 10.1130/0016-7606(1999)111<1757:CNBVAA>2.3.CO;2.

Braun-Blanquet, J. (1964). Pflanzensoziologie. Grundzüge der vegetationskunde. Wien, New York: Springer Verlag.

Globevnik, L. \& Mikoš M. (2009). Boundary conditions of morphodynamic processes in the Mura River in Slovenia. Catena, 79(3), 265-276. DOI: 10.1016/j.catena.2009.06.008.

Góczán, L. \& Lóczy D. (1990). The Slovak-Hungarian barrage system on the Danube river and its environmental problems. Geographica Polonica, 58, 89-98.

Illyová, M. \& Matečný I. (2014). Ecological validity of river-floodplain system assessment by planktonic crustacean survey (Branchiata: Branchiopoda). Environ. Monit. Assess., 186(7), 4195-4208. DOI: 10.1007/s10661-0143690-0.

Jansky, L., Masahiro, M. \& Pachova N.I. (2004). The Danube: Environmental monitoring of an international river. Hong Kong: United Nations University Press.

Klasz, G., Reckendorfer, W., Gabriel, H., Baumgartner, C., Schmalfuss, R. \& Gutknecht D. (2014). Natural levee formation along a large and regulated river: The Danube in the National Park Donau-Auen, Austria. Geomorphology, 215, 20-33. DOI: 10.1016/j.geomorph.2013.12.023.

Lehotský, M., Novotný, J., Szmańda, J.B. \& Grešková A. (2010). A suburban inter-dike river reach of a large river: Modern morphological and sedimentary changes (the Bratislava reach of the Danube river, Slovakia). Geomorphology, 117, 298-308. DOI: 10.1016/j.geomorph.2009.01.018.

Lehotský, M., Horáčková, Š. \& Sládek J. (2013). Morfologicko-sedimentové zmeny by-pasovaného koryta vodného toku - príklad starého koryta Dunaja. Geomorphologia Slovaca et Bohemica, 2, 41-49.

Liébault, F. \& Piégay H. (2001). Assessment of channel changes due to long-term bedload supply decrease, Roubion River, France. Geomorphology, 36(3-4), 167-186. DOI: 10.1016/S0169-555X(00)00044-1.

Liébault, F. \& Piégay H. (2002). Causes of 20th century channel narrowing in mountain and piedmont rivers of southeastern France. Earth Surface Processes and Landforms, 27(4), 425-444. DOI: 10.1002/esp.328.

Nakamura, F., Yajima, T. \& Kikuchi S. (1997). Structure and composition of riparian forests with special reference to geomorphic site conditions along the Tokachi River, northern Japan. Plant Ecology, 133, 209-219. DOI: 10.1023/A:1009787614455.

Otahel’ová, H., Valachovič, M. \& Hrivnák R. (2007). The impact of environmental factors on the distribution pattern of aquatic plants along the Danube River corridor (Slovakia). Limnologica-Ecology and Management of Inland Waters, 37(4), 290-302. DOI: 10.1016/j.limno.2007.07.003.

Pekárová, P., Halmová, D., Mitková Bačová, V., Miklánek, P., Pekár, J. \& Škoda P. (2013). Historic flood marks and flood frequency analysis of the Danube river at Bratislava, Slovakia. Journal of Hydrology and Hydromechanics, 61(4), 326-333. DOI: 10.2478/johh-2013-0041.

Surian, N. (1999). Channel changes due to river regulation: the case of the Piave River, Italy. Earth Surface Processes and 
Landforms, 24(12), 1135-1151. DOI: 10.1002/(SICI)1096-9837(199911)24:12<1135::AID-ESP40>3.0.CO;2-F.

Szlauer-Lukaszewska, A. (2015). Effects of river bed regulation on habitats and communities: A case study for ostracods in the Oder River, Poland. International Review of Hydrobiology, 100(2), 69-78. DOI: 10.1002/ iroh.201401738.

Uherčíková, E. \& Némethová D. (2006). The dynamics of Bodícka brána forest vegetation. Biologia, 61(4), 421-431.

Vojtková, J., Minarič, P. \& Kollár J. (2014). Production-ecological analysis of herb layer in the softwood floodplain forests formed after the gabčíkovo waterwork construction and their characteristics. Ekológia (Bratislava), 33(1), 9-15. DOI: 10.2478/eko-2014-0002.

Vranovský, M. (1997). Impact of the Gabčíkovo hydropower plant operation on planctonic copepods assemblages in the River Danube and its floodplain downstream of Bratislava. Hydrobiologia, 347, 41-49. DOI: 10.1023/A:1002990705205. 